Brit. J. vener. Dis (1966), 42, 210.

\title{
METRONIDAZOLE AND PREGNANCY*
}

\author{
BY \\ PHILIP RODIN AND GERALD HASS \\ From the Department of Venereology, The London Hospital
}

Since metronidazole is so widely used, it is important to know whether there is any risk from giving the drug during pregnancy. Many drugs are now withheld during early pregnancy, unless their administration is considered essential. There are, however, patients to whom drugs are given before the existence of pregnancy is recognized. In such cases there may be risks of foetal malformations.

Apart from the study by Scott-Gray (1964), there have been few reports of the outcome of pregnancies in which metronidazole was given to the mother in the first trimester. The present report describes some findings at The London Hospital which, although limited as regards numbers, were thought worth reporting in the hope that others would record their own experiences.

\section{Material and Methods}

During 1961 and 1962, 78 pregnant patients received metronidazole in doses of $200 \mathrm{mg}$. three times daily for 7 days. Most were attending the Whitechapel Clinic but a small number were treated at the ante-natal clinic. Most of the babies were delivered at hospitals other than The London Hospital and information regarding the pregnancies and babies was obtained from the records at these hospitals or by visiting the patients. The duration of pregnancy when the drug was given was dated from the first day of the last menstrual period. In 1962 and subsequently, comparatively few patients were given the drug because it became the policy of the clinic to avoid its use during pregnancy until more information about its effects was available.

\section{Results}

The outcome of the pregnancy was known in 61 cases. The remaining seventeen women could not be traced. The stage of pregnancy when treatment was given in the 61 cases is shown in Table I. Ten received the drug in the first 8 weeks of pregnancy.

\footnotetext{
* Received for publication November 6, 1965.
}

57 patients gave birth to living full-term infants with no congenital malformations.

TABle I .

STAGE OF PREGNANCY OF 61 PATIENTS

\begin{tabular}{|c|c|c|c|c|}
\hline \multicolumn{4}{|c|}{ Trimester } & Number \\
\hline $1 \mathrm{st}$ & . & $\begin{array}{l}4 \text { wks } \\
5-8 \text { wks } \\
9-12 \text { wks }\end{array}$ & $\begin{array}{l}\ldots \\
\cdots \\
\cdots\end{array}$ & $\left.\begin{array}{l}3 \\
7 \\
3\end{array}\right\}$ \\
\hline 2nd & . & $\ldots$ & . & 29 \\
\hline 3rd & $\ldots$ & $\ldots$ & $\ldots$ & 19 \\
\hline
\end{tabular}

Three gave birth to premature stillborn infants but none showed any malformations. In two instances the stillbirth occurred 8 weeks and 6 months respectively after treatment with metronidazole. In the other, a retroplacental haemorrhage occurred 3 days after starting metronidazole, but the patient had hypertension and was also receiving intravenous iron injections.

One patient, who was treated in the fifth month of pregnancy, gave birth to a full-term infant who suffered from white asphyxia and could not be resuscitated. No malformations were found post mortem.

\section{Discussion}

Although several workers have mentioned that they have given metronidazole to pregnant patients without ill-effects, relatively few have mentioned the stages of pregnancy at which the drug was given. Trials undertaken in ante-natal clinics are likely to include patients mainly in the second and third trimesters of pregnancy. Scott-Gray (1964) reported a large series in which 79 patients were treated in the first trimester, but did not state how many of them were treated in the first 8 weeks which is the period in which organogenesis takes place. 
The results reported by various workers are shown in Table II. In no instance could any congenital malformation be attributed to the drug and the incidence of malformations was no higher than that expected by chance. However, there is no information about effects, such as deafness, which would not be detected until some time after birth.

Animal experiments performed by Cosar, Ganter, and Julou (1961) failed to show any deleterious effects on the foetuses of rats given 50 to $100 \mathrm{mg}$. per $\mathrm{kg}$. metronidazole daily by mouth. Ingham (1963), using rabbits and rats, also failed to show any teratogenic action.

\section{Summary}

No instance of congenital malformation was observed in the infants of 61 mothers who received metronidazole during pregnancy; thirteen mothers were given the drug in the first 12 weeks of pregnancy.

Sufficient evidence is available to indicate the safety of metronidazole when given in the second and third trimesters of pregnancy. Although there is no evidence of deleterious effects of the drug when given in the first trimester, there are as yet too few reported cases to be certain of its safety. It is hoped that other workers will report their findings.

TABLE II

OUTCOME OF PREGNANCY IN PATIENTS TREATED WITH METRONIDAZOLE

\begin{tabular}{|c|c|c|c|c|c|c|c|}
\hline Authors & Date & $\begin{array}{l}\text { Daily } \\
\text { Dose } \\
\text { (mg.) }\end{array}$ & $\begin{array}{c}\text { Days of } \\
\text { Treatment }\end{array}$ & $\begin{array}{l}\text { Total } \\
\text { Treated }\end{array}$ & $\begin{array}{l}\text { No. in first } \\
\text { Trimester }\end{array}$ & $\begin{array}{l}\text { No. with } \\
\text { known } \\
\text { Outcome }\end{array}$ & $\begin{array}{l}\text { Foetal Death or } \\
\text { Abnormality }\end{array}$ \\
\hline Robinson and Johnston & 1961 & 500 & 10 & 100 & Not stated & 93 & $\begin{array}{l}1 \text { with hydrocephalus } \\
1 \text { with umbilical hernia } \\
1 \text { with skin tag on ear }\end{array}$ \\
\hline Watt and Jennison & 1962 & 600 & 7 & 23 & Not stated & 19 & $\begin{array}{l}1 \text { with anencephaly } \\
1 \text { non-surgical abortion }\end{array}$ \\
\hline Schram and Kleinman & 1962 & 500 & 10 & 26 & Not stated & 26 & 1 stillbirth 5 weeks after treatment \\
\hline Williams & 1962 & 1000 & 10 & 14 & Not stated & $* ? 14$ & None \\
\hline $\begin{array}{ccc}\text { Zacharias, Salzer, Gunn, and } \\
\text { Dierksheide } & . & .\end{array}$ & 1963 & 1000 & 10 & 39 & Not stated & 34 & 1 stillbirth (Rh. incompatibility) \\
\hline Monroe & 1963 & $100-1000$ & 10 & 25 & 10 & $? 25$ & None \\
\hline Lyon, Sinykin, and Barr & 1963 & $500-750$ & 10 & 11 & 3 & 9 & None \\
\hline Perl and Ragazzoni & 1963 & 750 & 10 & 100 & 6 & 49 & None \\
\hline Andrews and Andrews & 1963 & 500 & 10 & 27 & 7 & 19 & 2 abortions \\
\hline \begin{tabular}{cccr|} 
Narang, Bhargava, & \multicolumn{3}{c|}{ Chohan, } \\
and $\mathbf{R}$ ao &. & $\ldots$ &. \\
\end{tabular} & 1963 & 600 & 7 & 14 & Not stated & $? 14$ & None \\
\hline Whitelaw, Fox, and Schlichting & 1963 & 750 & 10 & 5 & 1 & 5 & None \\
\hline $\begin{array}{ll} & \ldots \\
\end{array}$ & 1963 & 600 & $7-10$ & 21 & Not stated & 7 & None \\
\hline Gardner and Dukes .. & 1964 & 1000 & 5 & 18 & Not stated & $? 18$ & None \\
\hline Pereyra and Lansing. . & 1964 & 750 & $3-10$ & 42 & None & $? 42$ & None \\
\hline Kotcher, Frick, and Giesel .. & 1964 & 1000 & 10 & 36 & None & 35 & $\begin{array}{l}1 \text { with "crooked feet" (mother } \\
\text { treated in third trimester) } \\
1 \text { abortion (foetal heart not heard } \\
\text { for } 1 \text { month before treatment) }\end{array}$ \\
\hline Scott-Gray $\quad .$. & 1964 & 600 & 7 & 295 & 79 & 290 & $\begin{array}{c}1 \text { with anencephaly } \\
1 \text { with microcephaly } \\
1 \text { with multiple defects } \\
1 \text { with hydrocephalus } \\
2 \text { non-surgical abortions } \\
\begin{array}{l}\text { nll } \\
\text { mothers } \\
\text { late pred in } \\
\text { nancy }\end{array} \\
\text { mother had Rh. incompatibility } \\
\text { and } 1 \text { had heart disease) } \\
6 \text { stillbirths ( } 2 \text { cord strangulation, } \\
3 \text { pre-eclampsia, 1 anencephaly) }\end{array}$ \\
\hline Parker, Thomas, and Jones .. & 1965 & $500-750$ & 10 & 36 & Not stated & $? 36$ & None \\
\hline Rodin and Hass & Present study & 600 & 7 & 78 & 18 & 61 & $\begin{array}{l}3 \text { stillbirths (none showed mal- } \\
\text { formations) }\end{array}$ \\
\hline
\end{tabular}

*? Before a number indicates that it is not clear from the report that all these patients were followed. 
We should like to thank Miss L. I. Ponting who helped with the tracing of the patients.

\section{REFERENCES}

Andrews, M. C., and Andrews, W. C. (1963). Sth. med.J. (Bgham, Ala.), 56, 1214.

Cosar, C., Ganter, P., and Julou, L. (1961). Presse med., 69, 1069

Csonka, G. W. (1963). Brit. J. vener. Dis., 39, 258.

Gardner, H. L., and Dukes, C. D. (1964). Amer. J. Obstet. Gynec., 89, 990.

Ingham, B. (1963). Personal communication.

Kotcher, E., Frick, C. A., and Giesel, L. O. (1964). Amer. J. Obstet. Gynec., 88, 184.

Lyon, F. A., Sinykin, M. B., and Barr, M. M. (1963). Ibid., 85, 955.

Monroe, S. E. (1963). Calif. Med., 98, 256.

Narang, S. S., Bhargava, N. C., Chohan, B. K., and Rao, M. S. (1963). J. Obstet. Gynaec. India, 13, 294.

Parker, R. T., Thomas, W. L., and Jones, C. P. (1965). Sth. med. J. (Bgham, Ala.), 58, 211.

Pereyra, A. J., and Lansing, J. D. (1964). Obstet. and Gynec., 24, 499.

Perl, G., and Ragazzoni, H. (1963). Ibid., 22, 376.

Robinson, S. C., and Johnston, D. W. (1961). Canad. med. Ass. J., 85, 1094.

Schram, M., and Kleinman, H. (1962). Amer. J. Obstet. Gynec., 83, 1284
Scott-Gray, M. (1964). J. Obstet. Gynaec. Brit. Cwlth, $71,82$.

Watt, L., and Jennison, R. F. (1962). Brit. med.J., 1, 276.

Whitelaw, M. J., Fox, L. P., and Schlichting, F. R. (1963). West. J. Surg., 71, 232.

Williams, B. F. P. (1962). Obstet. and Gynec., 20, 611.

Zacharias, L. F., Salzer, R. B., Gunn, J. C., and Dierksheide, E. B. (1963) Amer.J. Obstet. Gynec., 86, 748.

\section{La metronidazole et la grossesse}

\section{RÉSUMÉ}

Aucun cas de malformation congénitale n'a été observé chez les bébés de 61 mamans qui avaient reçu de la métronidazole pendant la grossesse; 13 mamans avaient pris le médicament pendant les premières douze semaines de la grossesse.

Il y a suffisamment de preuve pour indiquer que la métronidazole peut être donné sans risque pendant le second et le troisième trimestre de la grossesse. Quoiqu'il n'y ait pas de preuve d'un seul effet nuisible quand le médicament est donné pendant les premiers trois mois de la grossesse, il y a jusqu'a présent trop peu de cas rapportés pour être certain de son innocuité. Il est à souhaiter que d'autres observateurs publieront leurs conclusions. 